to the excellent "Ardeer Analytical Methods" book, but, so far as the reviewer is aware, this analytical process book is only available for private use in the Nobel Laboratories.

The book, which is printed in the United States, is excellently produced and the price reasonable compared with present-day standards. The increase in cost compared with the price of the former edition is less than proportional to the increase in size.

\section{J. Reilly.}

Evenings with the Stars. By Mary Procter. Pp. ix + $212+8$ plates. (London: Cassell and Co., Ltd., I924.) Ios. $6 d$. net.

THIS work is not to be confused with the "Children's Book of the Heavens" by the same author. It is an entirely new work and is intended for amateur astronomers, and for those who wish to learn something about the constellations, both in their appearance in the sky, and in the wealth of legendary lore connected with them. Accordingly, the division is into twelve evenings or chapters, each dealing with a certain number of constellations near to one another in the sky, until the whole of the constellations visible in northern latitudes have been passed in review. The work is, in a spirit of filial piety, dedicated to the father of the author, the late distinguished astronomer, R. A. Procter, "who taught me how to know and love the stars." From him she has inherited another gift, that of lucid and interesting description.

Each chapter is illustrated by a series of very clear and well-drawn original charts, by means of which the reader and student is safely piloted through the constellations. After a description of the constellation, the chief objects of interest are pointed out, with many aptly-chosen illustrative quotations from literary and legendary allusions to such objects. Appended to the twelve chapters is an interesting poem, the "Voices of the Suns," by the father of the author. There is also an excellent index, and in addition eight beautiful plates of nebulæ. The frontispiece in particular is a fine reproduction of the great cluster in Hercules, as photographed at the Dominion Astrophysical Observatory with the 72 -inch reflector.

The book, too, is very well printed. Both for its astronomical and its literary excellence it can be highly recommended, and is deserving of a wide circulation. It is the work, too, of an expert.

\section{A. L. C.}

The Soil and its Management. By Prof. Merritt F. Miller. Pp. vi +386 . (Boston and London: Ginn and Co., 1924.) $7 s .6 d$. net:

Prof. Miller's book is designed for schools teaching vocational agriculture and for short-course students in agricultural colleges, and forms an admirable introductory course in agriculture. Little or no acquaintance with chemistry and other sciences is assumed. The author has succeeded notably in avoiding technicalities and has produced a most interesting and readable account of soils, soil fertility, and soil management without losśs of clearness or accuracy.

The general arrangement is not very different from that adopted in most text-books dealing with the soil, but the treatment is unusually full for an elementary work, and the constant reference to farm practice and to observations and experiments which may readily be made on the farm and in the countryside is an attractive characteristic. At the end of each chapter there is a series of questions, together with skilfully selected practical exercises, both in the laboratory and in the field, and " home projects" for the benefit of the boy who lives on a farm. There are also references to more advanced books dealing with the various aspects of the subject. The numerous illustrations from photographs are another special feature : they are well reproduced and are very much to the point-particular mention may be made of the little series of pictures showing the crops in different rotations.

The author writes for American students and with American farming practice in view, and there is a good deal that is not directly applicable to conditions in Great Britain; but it is a work which all who have to do with the elementary teaching of agriculture will find most useful.

C. T. G.

Butterflies of India. By Chas. B. Antram. Pp. xvi+226. (Calcutta and Simla: Thacker, Spink and Co., I9z4.) 30 rupees.

THis book is intended for the uninitiated, and its primary object is to illustrate all the Indian butterflies, except a few which are very closely alike. More than 500 species are dealt with, leaving the Lycænidæ and Hesperiidæ for treatment in a second volume. A few notes on the collection and preservation of specimens are given, and the remainder of the book is occupied with short and, so far as possible, non-technical specific descriptions. The characters given for three out of the four families are popularised, we think, to the extent of inefficiency, while the Nymphalidæ are not diagnosed at all. Generic keys or tables are dispensed with, no doubt on account of the difficulty of translating them into non-technical language. The reader, therefore, needs to compare his specimens with the illustrations and descriptions until he alights upon the correct species. After a little practice he will probably experience no great difficulties in doing so.

The book is well produced and will, no doubt, prove to be a useful popular guide for the many collectors of these insects scattered through India. On p. 38 there is a description of a new species of Parnassius from Tibet: it is hoped that the author will also publish a technical diagnosis of the insect, if he has not already done so, in some scientific periodical.

Lehrbuch der anorganischen Chemie. Von Karl A. Hofmann. Fünfte Auflage. Pp. xiv $+76 \mathbf{x}+7$ Tafeln. (Braunschweig: F. Vieweg und Sohn A.-G., I924.) I7.50 gold marks.

Prof. Hofmann's text-book has been carefully revised and brought up-to-date. It gives a clear and fairly detailed account of the subject along recognised lines, including the rarer elements, and will be found useful by advanced students. As in most German textbooks, a section on explosives is added. It gives an impression that German students make a special study of this subject. 